\title{
Agromyces ulmi sp. nov., a xylanolytic bacterium isolated from Ulmus nigra in Spain
}

Correspondence

Martha E. Trujillo

mett@usal.es

\author{
Raúl Rivas, Martha E. Trujillo, Pedro F. Mateos, Eustoquio Martínez-Molina \\ and Encarna Velázquez
} Departamento de Microbiología y Genética, Edificio Departamental, Campus Miguel de
Unamuno, Universidad de Salamanca, Spain

\begin{abstract}
Two xylan-degrading bacterial strains were isolated from a decayed Ulmus nigra tree in Spain. The isolates were Gram-positive, non-motile, aerobic and formed substrate mycelium which fragmented into irregular rods. 16S rRNA gene sequence analysis indicated that the isolates form a separate branch within the genus Agromyces phylogenetic cluster, with Agromyces mediolanus DSM $20152^{\top}$ being their closest relative ( $97 \cdot 7$ and $97 \cdot 6 \%$ sequence similarity). Catalase, nitrate reduction and urease tests differentiated these strains from $A$. mediolanus. Cell-wall peptidoglycan composition, major menaquinone, predominant fatty acids and phospholipid pattern were typical of the genus Agromyces. The DNA G+C content determined for the type strain XIL01 ${ }^{\top}$ was $72 \mathrm{~mol} \%$. Based on the data presented, a novel species Agromyces ulmi sp. nov. is proposed. The type strain is $\mathrm{XILO}^{\top}\left(=\mathrm{LMG} 21954^{\top}=\mathrm{DSM} 15747^{\top}\right)$.
\end{abstract}

The genus Agromyces proposed by Gledhill \& Casida (1969) currently harbours ten species, including both nonfilamentous and filamentous, microaerophilic to aerobic, catalase- and oxidase-variable actinomycetes (Zgurskaya et al., 1992; Suzuki et al., 1996; Sasaki et al., 1998; Takeuchi \& Hatano, 2001; Li et al., 2003; Ortiz-Martinez et al., 2004). During a study of xylanolytic bacteria from decayed stumps of elm trees we isolated two strains designated XIL0 $1^{\mathrm{T}}$ and XIL05. The isolates showed the ability to hydrolyse xylan, a polymer of xylose present in plant cell walls.

The isolation of strains XIL01 ${ }^{\mathrm{T}}$ and XIL05 was performed on XED agar ( $7 \mathrm{~g}$ xylan, $3 \mathrm{~g}$ yeast extract and $25 \mathrm{~g}_{\text {agar }} \mathrm{l}^{-1}$ ) as described by Rivas et al. (2003). Cells grew as opaque white colonies on nutrient and XED agar media. Young cultures $(15 \mathrm{~h})$ produced branching substrate hyphae that broke into non-motile, diphtheroid and irregular rodshaped cells $(1 \cdot 3-2 \cdot 4 \times 0 \cdot 8-1 \cdot 0 \mu \mathrm{m})$ at later stages. Such cells usually appeared as branching rods when observed by phase-contrast microscopy. Aerial mycelium was not formed. The two strains stained Gram-positive (Doetsch, 1981).

Amplification of the 16S rRNA gene and its sequencing was performed according to Rivas et al. (2003). The MEGA2

Published online ahead of print on 23 April 2004 as DOI 10.1099/ ijs.0.63058-0.

Abbreviation: DAB, 2,4-diaminobutyric acid.

The GenBank/EMBL/DDBJ accession numbers for the 16S rRNA gene sequence of strains $\mathrm{XILO}^{\top}$ and XILO5 are AY427830 and AY427831, respectively. package (Kumar et al., 2001) was used to calculate phylogenetic distances according to the Kimura two-parameter method (Kimura, 1980) and the tree was constructed using the neighbour-joining algorithm (Saitou \& Nei, 1987); bootstrap analyses were based on 1000 resamplings.

Two 16S rRNA gene sequences of 1519 nucleotides were obtained for isolates XIL01 ${ }^{\mathrm{T}}$ and XIL05; two differences were found between the sequences of the two strains, which formed a separate branch within the genus Agromyces (Fig. 1). The sequences of strains XIL $01^{\mathrm{T}}$ and XIL05 showed $97 \cdot 7$ and $97 \cdot 6 \%$ similarity, respectively, with the sequence of Agromyces mediolanus DSM 20152 ${ }^{\mathrm{T}}$, which was the closest related species.

Biochemical and physiological properties of the two isolates investigated included carbon source assimilation, temperature growth rates and degradation of organic compounds (Rivas et al., 2003). Amylase, caseinase, catalase, oxidase and cellulase activities were detected as described by Rivas et al. (2003). The two strains grew between 15 and $37^{\circ} \mathrm{C}$, were negative for oxidase reaction and showed very similar results for the other characteristics studied; however, strain XIL05 could be differentiated from XIL01 ${ }^{\mathrm{T}}$ on the basis of assimilation of malate and arbutin degradation. Differential phenotypic characteristics between strains XIL0 $1^{\mathrm{T}}$ and XIL05 and their phylogenetically closest relatives are presented in Table 1. Other results are reported under the species description.

Isolates XIL01 ${ }^{\mathrm{T}}$ and XIL05 were grown on trypticase soy broth (Becton Dickinson, BBL) for 4 days at $28^{\circ} \mathrm{C}$ for chemotaxonomic characterization, which included analyses 


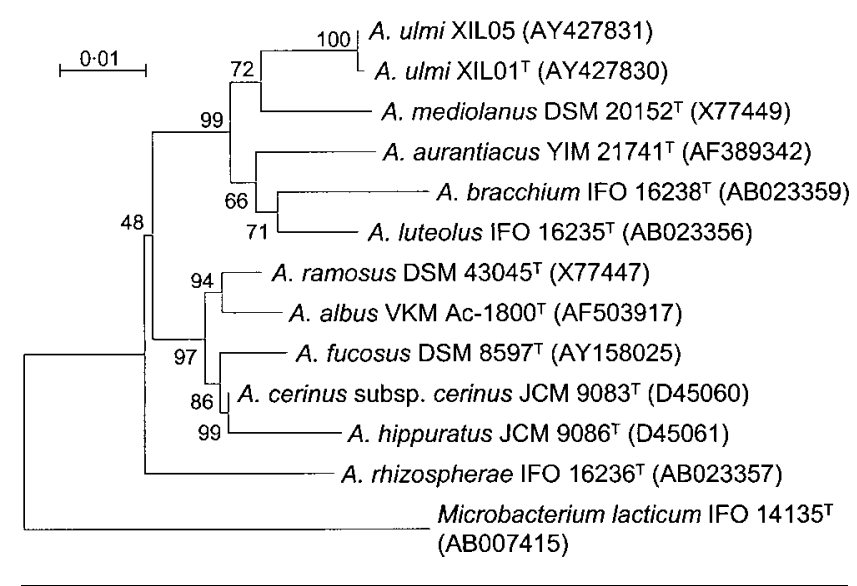

Fig. 1. Neighbour-joining tree derived from analysis of $16 \mathrm{~S}$ rRNA gene sequences (Kimura's two-parameter method) of isolates $\mathrm{XILO}^{\top}$ and XIL05 and related Agromyces species. Bootstrap percentages are indicated at branch points. Bar, 1 nucleotide substitution per 100 nucleotides. Microbacterium lacticum IFO $14135^{\top}$ was used as the outgroup.

of peptidoglycan composition, cell-wall sugars, cellular fatty acids, menaquinones and polar lipids. Studies were carried out according to the methods described by Schleifer \& Kandler (1972), Staneck \& Roberts (1974), Schleifer (1985) and Zimmermann et al. (1998).
Both strains contained 2,4-diaminobutyric acid (DAB), glycine and glutamic acid in their cell walls, but alanine was not found. This composition is consistent with the B2 $\gamma$ type peptidoglycan, which has been reported for all strains currently representing the genus Agromyces. Cell-wall sugars found in strains XIL0 $1^{\mathrm{T}}$ and XIL05 were rhamnose, fucose and glucose. Rhamnose and glucose have been reported for most species of the genus Agromyces, whereas fucose has been found only in Agromyces fucosus (Zgurskaya et al., 1992; Ortiz-Martinez et al., 2004).

The major fatty acids found for strains XIL0 ${ }^{\mathrm{T}}$ and XIL05 were anteiso- $\mathrm{C}_{15: 0}(46 \cdot 2$ and $45 \cdot 6 \%)$, iso- $\mathrm{C}_{16: 0}(25 \cdot 3$ and $24 \cdot 3 \%)$ and anteiso- $\mathrm{C}_{17: 0}(19 \cdot 6 \%$ and $22 \cdot 0 \%)$. This result is in agreement with other Agromyces species described (Suzuki et al., 1996; Takeuchi \& Hatano, 2001; Li et al., 2003).

HPLC analysis of the menaquinones revealed major amounts of MK-12 and MK-11 for both strains, a result that is also reported for many Agromyces species (Takeuchi \& Hatano, 2001; Dorofeeva et al., 2003). Isolate XIL0 ${ }^{\mathrm{T}}$ contained the menaquinones MK-12, -11, -10, -13 and $-9(50: 35: 11: 2: 2)$, whereas XIL05 contained MK-12, $-11,-13,-9$ and $-10(61: 23: 7: 4: 3)$. Polar lipids were only studied for strain XIL0 ${ }^{\mathrm{T}}$ and were composed of diphosphatidylglycerol, phosphatidylglycerol and glycolipid.

Table 1. Characteristics that differentiate Agromyces ulmi sp. nov. from other phylogenetically close Agromyces species

Data are from this study and Takeuchi \& Hatano (2001), Li et al. (2003) and Dorofeeva et al. (2003). +, Positive; -, negative; W, weak; ND, not determined.

\begin{tabular}{|c|c|c|c|c|c|}
\hline Characteristic & A. ulmi sp. nov. & A. luteolus & A. mediolanus & A. aurantiacus & A. bracchium \\
\hline Colony colour* & $\mathrm{W}$ & $\mathrm{Y}$ & Y & $\mathrm{O}, \mathrm{Y}, \mathrm{PG}, \mathrm{PW}$ & $\mathrm{Y}$ \\
\hline Hyphae & + & + & - & + & + \\
\hline Nitrate reduction & - & - & + & - & - \\
\hline Urease & - & - & + & - & - \\
\hline Gelatinase & - & + & ND & + & + \\
\hline Starch hydrolysis & - & + & - & + & + \\
\hline Catalase & - & + & + & - & + \\
\hline Growth at $37^{\circ} \mathrm{C}$ & + & - & ND & + & - \\
\hline \multicolumn{6}{|l|}{ Acid from: } \\
\hline Glycerol & + & - & + & + & - \\
\hline Ribose & + & - & + & - & + \\
\hline Galactose & + & - & + & + & + \\
\hline Mannitol & - & $\mathrm{W}$ & - & + & + \\
\hline Salicin & + & - & + & - & + \\
\hline Sucrose & + & $\mathrm{W}$ & + & + & + \\
\hline DNA $G+C$ content $(\mathrm{mol} \%)$ & $72 \cdot 0$ & $71 \cdot 1$ & $72 \cdot 3$ & $72 \cdot 8$ & $70 \cdot 0$ \\
\hline Cell-wall sugars $\dagger$ & Rha, Fuc, Glc & Rha, Fru, Glc, Man & $\mathrm{ND}$ & Rha, Gal, Glc, Man & Rha, Gal, Glc, Man \\
\hline Menaquinones $\ddagger$ & MK-12 $(-11,-10)$ & MK-12 (-11) & MK-12 (-11, -10) & MK-12 & MK-12 (-13) \\
\hline
\end{tabular}

${ }^{*} \mathrm{O}$, Orange; PG, pink-grey; PW, pink-white; $\mathrm{W}$, white; $\mathrm{Y}$, yellow.

$\dagger$ Fru, Fructose; Fuc, fucose; Glc, glucose; Man, mannose; Rha, rhamnose.

$\ddagger$ Menaquinones in parentheses are present as the next most common components. 
Determination of DNA base composition and DNA-DNA hybridization analyses were carried out as previously described by Rivas et al. (2003). The G+C contents of strains $\mathrm{XIL}^{\mathrm{T}}{ }^{\mathrm{T}}$ and XIL05 were $72 \cdot 0$ and $71 \cdot 7 \mathrm{~mol} \%$, respectively. DNA-DNA relatedness values between strains $\mathrm{XIL} 1^{\mathrm{T}}$ and XIL05, A. mediolanus DSM $20152^{\mathrm{T}}$ and Agromyces luteolus DSM $14595^{\mathrm{T}}$ were $100,48 \cdot 3$ and $53 \cdot 4 \%$, respectively, which clearly indicates the strains to be members of a separate genomic species (Wayne et al., 1987)

Thus, the results presented in this paper show that strains $\mathrm{XIL}^{\mathrm{T}}{ }^{\mathrm{T}}$ and XIL05 should be classified as a novel species within the genus Agromyces, for which the name Agromyces ulmi sp. nov. is proposed.

\section{Description of Agromyces ulmi sp. nov.}

Agromyces ulmi (ul'mi. L. fem. gen. n. ulmi of the elm tree, referring to the isolation source of this micro-organism).

Gram-positive and non-spore-forming bacterium. Young cultures produce branching substrate hyphae that break up into non-motile, diphtheroid and irregular-shaped cells after $15 \mathrm{~h}$. Aerial mycelium absent. Colonies on XED and nutrient agar are circular convex, white, opaque and usually $1-2 \mathrm{~mm}$ in diameter within 7 days at $28^{\circ} \mathrm{C}$. Aerobic; oxidase- and catalase-negative. Optimal growth temperature is $28^{\circ} \mathrm{C}$. Chemo-organotrophic. The following substrates are used as carbon sources: L-arabinose, cellulose, mannose, $\mathrm{N}$-acetylglucosamine, gentiobiose, maltose, starch and xylan. By contrast, adipate, caproate, citrate, malate, mannitol and phenylacetate are not used. Produces acid from glucose, glycerol, D-xylose, galactose, fructose, mannose, L-sorbose, rhamnose, methyl $\alpha$-D-mannoside, methyl $\alpha$-D-glucoside, $N$-acetylglucosamine, amygdalin, arbutin, salicin, cellobiose, lactose, maltose, melibiose, sucrose, trehalose, inulin, melezitose, raffinose, glycogen, xylitol, $\beta$-gentiobiose and D-lyxose. Aesculin is hydrolysed; caseinase, $\beta$-galactosidase and gelatinase are produced. Arginine dehydrolase, indole, tryptophan deaminase and urease are not produced. Nitrate is not reduced to nitrite. The peptidoglycan type is $\mathrm{B} 2 \gamma$. Other chemotaxonomic properties are described in the text and in Table 1.

The type strain, XIL01 ${ }^{\mathrm{T}}\left(=\mathrm{LMG} 21954^{\mathrm{T}}=\mathrm{DSM} 15747^{\mathrm{T}}\right)$, was isolated from the decayed stump of an elm tree, Ulmus nigra.

\section{Acknowledgements}

This work was supported by the CAICYT-DGES and JCyL (Spanish government). We thank M. Sánchez for the $16 \mathrm{~S}$ rRNA gene sequences. We also acknowledge the DSMZ staff for their help with chemotaxonomic and DNA-DNA hybridization analyses.

\section{References}

Doetsch, R. N. (1981). Determinative methods of light microscopy. In Manual of Methods for General Bacteriology, pp. 21-33. Edited by
P. Gerdhardt, R. G. E. Murray, R. N. Costilow, E. W. Nester, W. A. Wood, N. R. Krieg \& G. B. Phillips. Washington, DC: American Society for Microbiology.

Dorofeeva, L. V., Krausova, V. I., Evtushenko, L. I. \& Tiedje, J. M. (2003). Agromyces albus sp. nov., isolated from a plant (Androsace sp.). Int J Syst Evol Microbiol 53, 1435-1438.

Gledhill, W. E. \& Casida, L. E., Jr (1969). Predominant catalasenegative soil bacteria. III. Agromyces, gen. n., microorganisms intermediary to Actinomyces and Nocardia. Appl Microbiol 18, 340-349.

Kimura, M. (1980). A simple method for estimating evolutionary rates of base substitutions through comparative studies of nucleotide sequences. J Mol Evol 16, 111-120.

Kumar, S., Tamura, K., Jakobsen, I. B. \& Nei, M. (2001). Molecular Evolutionary Genetics Analysis Software. Tempe, AZ: Arizona State University.

Li, W.-J., Zhang, L.-P., Xu, P., Cui, X.-L., Xu, L.-H., Zhang, Z., Schumann, P., Stackebrandt, E. \& Jiang, C.-L. (2003). Agromyces aurantiacus sp. nov., isolated from a Chinese primeval forest. Int J Syst Evol Microbiol 53, 303-307.

Ortiz-Martinez, A., Gonzalez, J. M., Evtushenko, L. I., Jurado, V., Laiz, L., Groth, I. \& Saiz-Jimenez, C. (2004). Reclassification of Agromyces fucosus subsp. hippuratus as Agromyces hippuratus sp. nov., comb. nov. and emended description of Agromyces fucosus. Int J Syst Evol Microbiol 54, 1553-1556.

Rivas, R., Sánchez, M., Trujillo, M. E., Zurdo-Piñeiro, J. L., Mateos, P. F., Martínez-Molina, E. \& Velázquez, E. (2003). Xylanimonas cellulosilytica gen. nov., sp. nov., a xylanolytic bacterium isolated from a decayed tree (Ulmus nigra). Int J Syst Evol Microbiol 53, 99-103.

Saitou, N. \& Nei, M. (1987). The neighbor-joining method: a new method for reconstructing phylogenetic trees. Mol Biol Evol 4, 406-425.

Sasaki, J., Chijimatsu, M. \& Suzuki, K. (1998). Taxonomic significance of 2,4-diaminobutyric acid isomers in the cell wall peptidoglycan of actinomycetes and reclassification of Clavibacter toxicus as Rathayibacter toxicus comb. nov. Int J Syst Bacteriol 48, 403-410.

Schleifer, K. H. (1985). Analysis of the chemical composition and primary structure of murein. Methods Microbiol 18, 123-156.

Schleifer, K. H. \& Kandler, O. (1972). Peptidoglycan types of bacterial cell walls and their taxonomic implications. Bacteriol Rev 36, 407-477.

Staneck, J. L. \& Roberts, G. D. (1974). Simplified approach to identification of aerobic actinomycetes by thin layer chromatography. Appl Microbiol 28, 226-231.

Suzuki, K., Sasaki, J., Uramoto, M., Nakase, T. \& Komagata, K. (1996). Agromyces mediolanus sp. nov., nom. rev., comb. nov., a species for "Corynebacterium mediolanum" Mamoli 1939 and for some aniline-assimilating bacteria which contain 2,4-diaminobutyric acid in the cell wall peptidoglycan. Int J Syst Bacteriol 46, 88-93.

Takeuchi, M. \& Hatano, K. (2001). Agromyces luteolus sp. nov., Agromyces rhizospherae sp. nov. and Agromyces bracchium sp. nov., from the mangrove rhizosphere. Int J Syst Evol Microbiol 51, 1529-1537.

Wayne, L. G., Brenner, D. J., Colwell, R. R. \& 9 other authors (1987). Report of the ad hoc committee on reconciliation of approaches to bacterial systematics. Int J Syst Bacteriol 37, 463-464.

Zgurskaya, H. I., Evtushenko, L. I., Akimov, V. N., Voyevoda, H. V., Dobrovolskaya, T. G., Lysak, L. V. \& Kalakoutskii, L. V. (1992). Emended description of the genus Agromyces and description of 
Agromyces cerinus subsp. cerinus sp. nov., subsp. nov., Agromyces cerinus subsp. nitratus sp. nov., subsp. nov., Agromyces fucosus subsp. fucosus sp. nov., subsp. nov., and Agromyces fucosus subsp. hippuratus sp. nov., subsp. nov. Int J Syst Bacteriol 42, 635-641.
Zimmermann, O., Spröer, C., Kroppenstedt, R. M., Fuchs, E., Köchel, H. G. \& Funke, G. (1998). Corynebacterium thomssenii sp. nov., a Corynebacterium with $N$-acetyl- $\beta$-glucosaminidase activity from human clinical specimens. Int J Syst Bacteriol 48, 489-494. 